\title{
Spatial patterns in species assemblages associated with the northwestern Gulf of Mexico shrimp trawl fishery
}

\author{
Melissa H. Monk ${ }^{1,3,4, *}$, Joseph E. Powers ${ }^{1}$, Elizabeth N. Brooks ${ }^{2}$ \\ ${ }^{1}$ Department of Oceanography and Coastal Sciences, School of the Coast and Environment at Louisiana State University, \\ Energy, Coast and Environment Building, Baton Rouge, LA 70803, USA \\ ${ }^{2}$ Northeast Fisheries Science Center, National Marine Fisheries Service, NOAA, 166 Water St., Woods Hole, MA 02543, USA \\ ${ }^{3}$ Present address: Center for Stock Assessment Research, Department of Applied Mathematics and Statistics, \\ Jack Baskin School of Engineering, University of California, Santa Cruz, CA 95064, USA \\ ${ }^{4}$ Present address: Fisheries Ecology Division, Southwest Fisheries Science Center, National Marine Fisheries Service, NOAA, \\ 110 Shaffer Road, Santa Cruz, CA 95060, USA
}

ABSTRACT: The shrimp trawl fishery in the Gulf of Mexico (GOM) removes a diverse community of bycatch species from the Gulf Large Marine Ecosystem (LME). A small fraction of the discarded species is economically important, and little is known about the majority of bycatch species. Large-scale fisheryindependent trawl surveys from the Southeast Area Monitoring and Assessment Program (SEAMAP) were utilized to examine the spatial dynamics of the demersal fish community associated with the shrimp trawl fishery across the northwest GOM-LME. Multivariate analyses revealed 3 distinct demersal fish communities from the fall survey and 4 distinct communities from the summer survey. Shrimp Statistical Zone 13, nearest the Mississippi River, was a differentiating factor between the 2 surveys, associating with Zones 14 and 15 in the fall survey, and comprising its own dissimilar community in the summer survey. The dominant species within each zone differed between the summer and fall seasons, which can be explained by the time of spawning and seasonal ontogenetic migrations of species associated with the survey. Indicator species analysis identified species in each season and region that can be used to monitor future ecosystem changes within these regions.

KEY WORDS: SEAMAP · Fish community · Indicator species $\cdot$ Bycatch $\cdot$ Large marine ecosystem

$$
\begin{gathered}
\text { Resale or republication not permitted without } \\
\text { written consent of the publisher }
\end{gathered}
$$

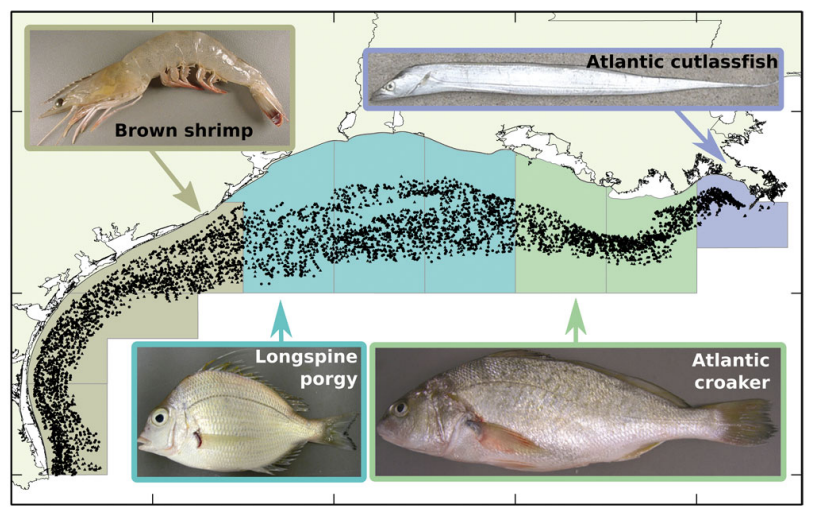

Northwestern Gulf of Mexico demersal fish communities (DFCs) identified from SEAMAP bottom trawl surveys (points) and example indicator species.

Image: Melissa Monk (map), Brenda Bowling (fish photos)

\section{INTRODUCTION}

Ecosystem-based fisheries management (EBFM) is a process under which more holistic approaches are introduced than those considered by more traditional single-species management. EBFM is often framed at the scale of large marine ecosystems (LMEs; Pikitch et al. 2004, Link 2010). Implementation of EBFM has increased the need for data to quantify relationships among species within an ecosystem, the spatial dynamics of the system, and the impact of anthropo- 
genic activities. An important part of the EBFM process is to evaluate community structure of major LMEs such as the US Gulf of Mexico (GOM). The GOMLME spans the coastline of 5 states and is divided into 2 distinct systems by the Mississippi River Delta outflow. Here we focus on the spatial dynamics of the demersal fish community (DFC) associated with the northwestern GOM (Fig. 1) shrimp trawl fishery.

Shrimp trawl gear alters the physical environment of the seafloor and also catches a large biomass and diversity of bycatch species, i.e. species that are caught in trawls associated with shrimp and are subsequently discarded (Churchill 1989, Watling \& Norse 1998, Duplisea et al. 2002). The removal of large volumes of bycatch species has the potential to change species biodiversity and species distribution patterns (Bohnsack 1998, Rice 2000, Board 2002, Barnes \& Thomas 2005, Løkkeborg 2005). Many of the species caught as bycatch in the GOM are neither commercially nor recreationally harvested species and have not been monitored as closely as species with high economic value. Of the 199 species identified by observers in the GOM shrimp trawl fishery, only 14 were identified as recreationally, commercially, or ecologically important (13 finfish and a 'general shark' category; Scott-Denton et al. 2012). All of the commercially and recreationally important species are managed as single-species fisheries. However, an understanding of the spatial dynamics of the species along the northwestern GOM will aid in future EBFM of these species.

Few studies have examined the biodiversity and community assemblage patterns in the northwestern GOM using fisheries-independent data. Studies that were conducted focused on specific areas of the GOM, the effect of oil and gas platforms on community

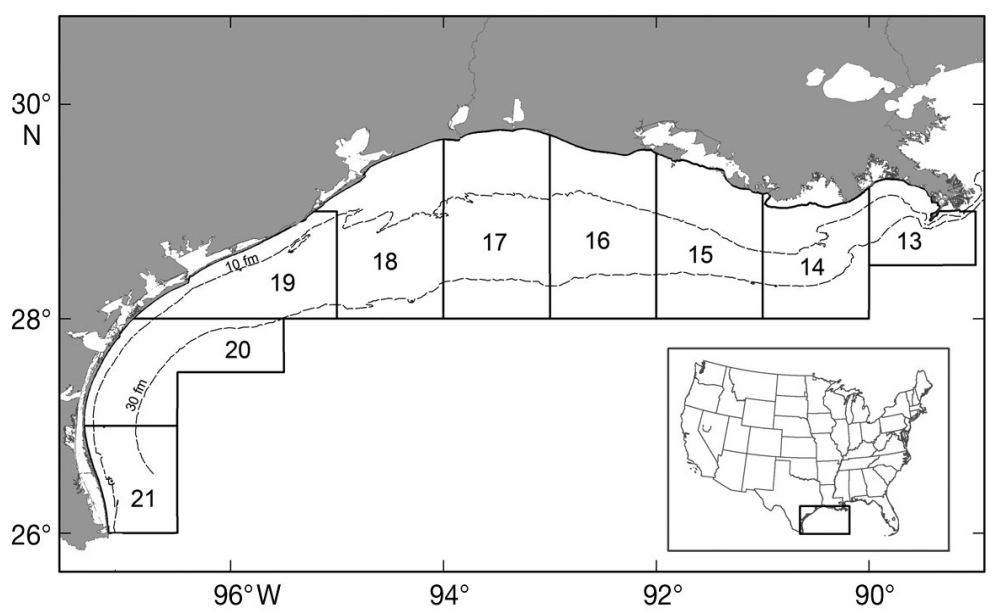

Fig. 1. Northwestern Gulf of Mexico shrimp statistical zone delineations assemblages, and the effect of trawling on specific species (Chittenden \& McEachran 1976, Stanley \& Wilson 1997, Wells et al. 2008). The Southeast Area Monitoring and Assessment Program (SEAMAP), a fishery-independent trawl survey conducted in the northwestern GOM, provides a data set useful for investigating the spatial dynamics of the demersal fish community (Eldridge 1988). The trawl survey includes all species captured as bycatch in the shrimp trawl fishery, but without the potential biases introduced by using fishery-dependent data. We conducted multivariate analyses to infer the spatial structure of the demersal fish community in the northwestern GOM. Using the regions identified from the multivariate analyses, we then conducted an indicator species analysis to define a list of species that can be used to monitor the regions as part of an ecosystem approach to fisheries management.

\section{MATERIALS AND METHODS}

\section{Data sources}

SEAMAP is a collaborative program for the collection of fisheries-independent data in the southeastern USA. We used the annual summer and fall shrimp and groundfish trawl surveys to identify changes in community composition in the northwestern GOM. We constrained the dataset to the time period prior to the fall of 2008, after which survey sampling methods changed (NOAA 2008). The summer survey is conducted in June and July, with data available from 1982 to 2008, and the fall survey is conducted in October and November and data were available from 1986 to 2007 (Eldridge 1988).

The SEAMAP survey was stratified by the shrimp statistical zones that are used for management of the shrimp trawl fishery (Patella 1975) (Fig. 1). We only use Zones 13 to 21 in the northwestern GOM and tows in the depth range 10 to 30 fathoms ( $\mathrm{fm} ; 18.3-$ $54.9 \mathrm{~m})$. In depths of less than $10 \mathrm{fm}(18.3 \mathrm{~m})$, trawls other than the SEAMAP-standard trawl $40 \mathrm{ft}$ (12.2 m) headrope were common. The depth range was also chosen to reflect the depths over which the majority of the shrimp fishery effort affects economically important species, specifically red snapper Lutjanus campechanus (Gallaway et al. 2003). There were 2 missing years of data (1983 and 1986) for the summer survey in Zone 13. 
We examined the database for errors and anomalies in individual tows. Tows using gear other than the standard SEAMAP shrimp trawl $(40 \mathrm{ft}$ [12.2 $\mathrm{m}$ ] headrope) were excluded from these analyses as well as tows in which significant gear malfunctions were noted, e.g. trawl doors did not open. For stations that deployed paired tows, only 1 tow was selected for analysis to keep the samples as balanced as possible. We also constrained the data to tows falling within the standard tow times of 10 to $55 \mathrm{~min}$. Trawls are towed perpendicular to the depth contour and are towed until the entire depth stratum is sampled (Eldridge 1988). We retained stations with tow times from 55 to $80 \mathrm{~min}$ if the standard protocols were followed, as well as stations that required 2 tows to cover the depth stratum. The maximum tow time was $70 \mathrm{~min}$ for the summer data and $79 \mathrm{~min}$ for the fall data. Details for individual cruises can be obtained in the SEAMAP environmental and biological atlases and the individual cruise reports (NOAA 2008, Rester et al. 2008).

More than 800 species were present in the SEAMAP groundfish trawl surveys. The catch, both in terms of biomass and number of individuals, was dominated by a few abundant species. Including rare species in community composition analyses has the potential to bias results (Koch 1987, Mueter \& Norcross 2000). Therefore, we considered species present in fewer than $10 \%$ of all tows to be 'rare' in the survey, and excluded them from analyses. In addition, we excluded gelatinous zooplankton species due to inconsistent sampling of these species over time (J. Rester pers. comm.).

We calculated a yearly index of catch per unit effort (CPUE) prior to analysis for each species. The index of abundance was calculated from the CPUE for each zone $(z)$, survey season $(s)$, and year $(y)$. We also calculated the index by pooling catch across years. The index multiplies the geometric mean of species $i$ abundance per tow-hour $\left(x_{i}\right)$, in a specific zone $(z)$, season $(s)$, and year $(y$, when applicable), by the proportion of tows in which a species was observed, where $n$ is the number of tows in which the species was observed, and $T$ is the total number of tows (Conners et al. 2002).

$$
\operatorname{Index}_{i, Z, S, Y}=\frac{\left(\Pi_{i=1}^{n} X_{i, Z, S, Y}\right)^{\frac{1}{n_{i, Z, S, Y}} * n_{i, Z, S, Y}}}{T_{i, Z, s, y}}
$$

The indices of abundance were then arranged into a matrix where rows represented shrimp statistical zone/year combinations and columns represented species.

\section{Statistical analyses}

The chord distance $\left(D_{\text {chord }}\right)$, or relative Euclidian distance, was chosen as the distance metric to use for the multivariate analyses (Legendre \& Legendre 1998, McCune et al. 2002). The metric measures the dissimilarity of species composition among shrimp statistical zones by comparing the abundance index (a) of species $i$ between pairs of shrimp statistical zones ( $j$ and $k$ ), for all $p$ species, over all years.

$D_{\text {chord }(j k)}=\delta_{j k}=\sqrt{\sum_{i=1}^{p}\left[\left(\frac{a_{j i}}{\sqrt{\sum_{i=1}^{p} a_{j i}^{2}}}\right)-\left(\frac{a_{k i}}{\sqrt{\sum_{i=1}^{p} a_{k i}^{2}}}\right)\right]^{2}}$

The contribution of species $i$ to the dissimilarity $(\delta)$ between a pair of shrimp statistical zones $(j, k)$ is:

$$
\delta_{j k}(i)=\frac{\left(a_{j i}-a_{k i}\right)^{2}}{\delta_{j k}}
$$

The chord distance measure is equivalent to taking the Euclidian distance after normalizing the row (shrimp statistical zone) totals so the marginal sum of squares is 1 (Orloci 1967, McCune et al. 2002). This ensures that no single species dominates the calculation of the dissimilarity matrix. This also gives the sample units (shrimp statistical zones) the same weight, making the differences in effort among those sample units irrelevant.

We analyzed the spatial patterns in species composition among shrimp statistical zones using 2 multivariate analyses: non-metric multidimensional scaling (NMDS; Shepard 1962, Kruskal 1964) and agglomerative hierarchical cluster analysis (Ward 1963). NMDS is an ordination method that performs well when data are non-normal and preserves the rank order distances from any dissimilarity measure (Clarke 1993). Stress, a goodness-of-fit statistic, was used to determine the number of retained dimensions from the NMDS. Stress is the departure from monotonicity between distances in the original dissimilarity matrix and the $k$-dimensional ordination space, with a value less than 0.3 considered acceptable (Clarke \& Warwick 2001). Cluster analysis was used in parallel to corroborate the patterns observed in the NMDS analysis to classify regional groupings of species similarity among the shrimp statistical zones.

To determine which species were responsible for the regional groupings identified in the multivariate analyses, we partitioned the dissimilarity matrix and conducted an indicator species analysis (Clarke 1993). We computed the average contribution of each species to the overall average dissimilarity $(\bar{\delta})$ between 2 distinct communities identified from the 
multivariate analyses. The $\bar{\delta}$ is found by taking the mean of the dissimilarity between pairs of shrimp statistical zones within the 2 DFCs being compared. The average contribution of each species $\left(\delta_{i}\right)$ to the $\bar{\delta}$ was found by taking the mean of $\delta_{j k}(i)$ from all pairs of shrimp statistical zones in the 2 DFCs being compared. Clarke (1993) defined a species as a good discriminating species if it contributed a high proportion to $\bar{\delta}$ and had a small standard deviation $\left(\mathrm{SD}\left[\delta_{i}\right]\right)$, meaning a species contributed consistently to the dissimilarities. Species were ranked by their percent contribution to the dissimilarity between any 2 DFCs, and we present the results for species contributing to the cumulative $90 \%$ difference between any 2 DFCs.

Indicator species analysis provides a metric to determine a species' affinity to a specific spatial area using the species' relative abundance (specificity) and its relative frequency (fidelity) from the sampled data (Dufrene \& Legendre 1997, McCune et al. 2002). Indicator species analysis provides another metric to compare the DFCs between seasons, and we were interested to see whether species contributing the most to the dissimilarity indices could be used as indicators for a particular DFC. An indicator value, Ind Val, was calculated for each species $i$ and for each DFC $d$ (pre-defined from the multivariate analysis results), according to the formula

$$
\text { Ind } V a l_{i d}=100 \times A_{i d} \times B_{i d}
$$

where $A_{i d}$ is a measure of the specificity and $B_{i d}$ is a measure of fidelity:

$$
\begin{aligned}
& A_{i d}=N \text { individuals }_{i d} / N \text { individuals }_{+d} \\
& B_{i d}=N \text { sites }_{i d} / N \text { sites }_{i+}
\end{aligned}
$$

In this study, $N$ individuals $s_{\text {id }}$ represents the mean

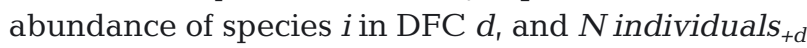
is the sum of mean abundances of species $i$ within all DFCs. $N$ sites $_{i d}$ is the number of shrimp statistical zones belonging to region $d$ where species $i$ is present. $N$ sites $_{i+}$ is the total number of shrimp statistical zones within DFC $d$. The IndVal has a maximum at 100 if individuals of a species are observed in all shrimp statistical zones in a given DFC and are absent from all other zones. We considered a species to be an indicator for a particular DFC if its maximum indicator value was $\geq 25$ (Dufrene \& Legendre 1997). For each species, the region with the largest indicator value, Ind $V a l_{\max }$ is reported. A randomization test (10 000 permutations) was used to test the statistical significance (Type I error, $\mathrm{p}<0.05$ ) of IndVal $l_{\max }$. Samples were randomly reassigned to shrimp statistical zones, and IndVal $I_{\max }$ was recalculated and compared to IndVal ${ }_{\max }$ from the data.
The NMDS and cluster analysis were programmed in R (R Core Development Team 2011) utilizing the Vegan community ecology package for the NMDS (Oksanen et al. 2010) and the cluster package for cluster analyses (Maechler et al. 2002). The indicator species analysis was conducted in PC-ORD (McCune \& Mefford 2006).

\section{RESULTS}

In total, 3305 tows were retained from the summer survey (Table S1 in the Supplement, available at www.int-res.com/articles/suppl/m519p001_supp.pdf) and 2849 from the fall survey (Table S2). The 67 species found in $10 \%$ or more tows in the summer survey (Table 1) represent $13 \%$ of all species identified to the species level in the summer survey. In the fall survey, 68 species were retained for the analyses, representing $14 \%$ of all species identified in the fall survey.

A cluster analysis using all survey data revealed differences in community composition between the summer and fall surveys within zones (Fig. S1 in the Supplement). Preliminary analyses also suggested no statistically significant temporal trends in the community assemblages (Monk 2012). Therefore, we analyzed summer and fall surveys independently, and pooled data across years for the NMDS and cluster analyses. Pooling data across years also maintained sample sizes adequate for our analyses.

\section{Summer groundfish survey}

The NMDS revealed 4 distinct groups of shrimp statistical zones: Zone 13, Zones 14 and 15, Zones 16 to 18, and Zones 19 to 21 (Fig. 2a). Three axes (stress $=0.001$ ) best explained the data, and upon visual inspection, the separation among shrimp zones was most visible in the first 2 axes.

In the cluster analysis, Zone 13 was again dissimilar from all other zones and formed its own branch in the dendrogram (Fig. 2b). Zones 14 to 18 formed a second distinct branch, and within that branch, Zones 14 and 15 and Zones 16 to 18 showed further separation of species composition. Zones 19 to 21 separated as a fourth unique group of species in the summer data. The repeatability of the results between the NMDS and the cluster analysis provides evidence that in the summer months, there are 4 distinct regional DFCs in the northwestern GOM. These regions represent a gradient of changing species composition starting at the mouth of the Mississippi 
Table 1. Classification of species present in at least $10 \%$ of all summer or fall trawls in the northwestern Gulf of Mexico. (-) Species not present in $\geq 10 \%$ of trawls in that season

\begin{tabular}{|c|c|c|c|c|c|}
\hline \multirow{2}{*}{$\begin{array}{l}\text { CLASS } \\
\text { Order }\end{array}$} & \multirow[t]{2}{*}{ Family } & \multirow[t]{2}{*}{ Scientific name } & \multirow[t]{2}{*}{ Common name } & \multicolumn{2}{|c|}{$\%$ trawls present } \\
\hline & & & & Summer & Fall \\
\hline \multicolumn{6}{|l|}{ OSTEICHTHYES } \\
\hline Anguilliformes & Muraenesocidae & Hoplunnis macrurus & Freckled pike-conger & 11 & - \\
\hline \multirow[t]{3}{*}{ Aulopiformes } & \multirow[t]{3}{*}{ Synodontidae } & Saurida brasiliensis & Brazilian lizardfish & 52 & 28 \\
\hline & & Synodus foetens & Inshore lizardfish & 72 & 79 \\
\hline & & Synodus poeyi & Offshore lizardfish & 16 & 11 \\
\hline Batrachoidiformes & Batrachoididae & Porichthys plectrodon & Atlantic midshipman & 33 & 30 \\
\hline \multirow[t]{4}{*}{ Clupeiformes } & \multirow[t]{3}{*}{ Clupeidae } & Etrumeus teres & Round herring & 12 & - \\
\hline & & Harengula jaguana & Scaled herring & 20 & 28 \\
\hline & & Opisthonema oglinum & Atlantic thread herring & - & 20 \\
\hline & Engraulidae & Anchoa hepsetus & Broad-striped anchovy & 27 & 18 \\
\hline Lophiiformes & Ogcocephalidae & Halieutichthys aculeatus & Pancake batfish & 28 & 32 \\
\hline Ophidiiformes & Ophidiidae & Lepophidium brevibarbe & Shortbread cusk eel & 32 & 28 \\
\hline \multirow[t]{28}{*}{ Perciformes } & \multirow[t]{4}{*}{ Carangidae } & Caranx crysos & Blue runner & - & 18 \\
\hline & & Chloroscombrus chrysurus & Atlantic bumper & 37 & 57 \\
\hline & & Selene setapinnis & Atlantic moonfish & 24 & 21 \\
\hline & & Trachurus lathami & Rough scad & 45 & 28 \\
\hline & Ephippidae & Chaetodipterus faber & Atlantic spadefish & - & 36 \\
\hline & Gerreidae & Eucinostomus gula & Jenny mojarra & 12 & 34 \\
\hline & Gobiidae & Bollmannia communis & Ragged goby & 16 & 10 \\
\hline & Haemulidae & Orthopristis chrysopterus & Pigfish & 34 & 11 \\
\hline & \multirow[t]{3}{*}{ Lutjanidae } & Lutjanus campechanus & Northern red snapper & 43 & 79 \\
\hline & & Lutjanus synagris & Lane snapper & 17 & 40 \\
\hline & & Pristipomoides aquilonaris & Wenchman & 31 & - \\
\hline & Mullidae & Upeneus parvus & Dwarf goatfish & 51 & 32 \\
\hline & \multirow[t]{6}{*}{ Sciaenidae } & Cynoscion arenarius & Sand seatrout & 33 & 52 \\
\hline & & Cynoscion nothus & Silver seatrout & 26 & 57 \\
\hline & & Larimus fasciatus & Banded drum & - & 23 \\
\hline & & Leiostomus xanthurus & Spot croaker & 21 & 63 \\
\hline & & Menticirrhus americanus & Southern kingcroaker & - & 10 \\
\hline & & Micropogonias undulatus & Atlantic croaker & 42 & 95 \\
\hline & Scorpaenidae & Scorpaena calcarata & Smoothhead scorpionfish & 10 & 20 \\
\hline & \multirow[t]{3}{*}{ Serranidae } & Centropristis philadelphicus & Rock sea bass & 65 & 61 \\
\hline & & Diplectrum bivittatum & Dwarf sand perch & 55 & 59 \\
\hline & & Serranus atrobranchus & Blackear bass & 34 & 26 \\
\hline & \multirow[t]{2}{*}{ Sparidae } & Lagodon rhomboides & Pinfish & - & 52 \\
\hline & & Stenotomus caprinus & Longspine porgy & 86 & 75 \\
\hline & Sphyraenidae & Sphyraena guachancho & Guachanche barracuda & - & 10 \\
\hline & Stromateidae & Peprilus alepidotus & American harvestfish & - & 17 \\
\hline & & Peprilus burti & Gulf butterfish & 62 & 53 \\
\hline & Trichiuridae & Trichiurus lepturus & Atlantic cutlassfish & 31 & 33 \\
\hline \multirow[t]{9}{*}{ Pleuronectiformes } & \multirow{6}{*}{$\begin{array}{l}\text { Archiridae } \\
\text { Bothidae }\end{array}$} & Gymnachirus texae & Gulf of Mexico fringed sole & - & 12 \\
\hline & & Ancylopsetta quadrocellata & Ocellated flounder species & 10 & 15 \\
\hline & & Cyclopsetta chittendeni & Mexican flounder & 27 & 42 \\
\hline & & Engyophrys senta & Spiny flounder & 12 & - \\
\hline & & Syacium gunteri & Shoal flounder & 50 & 63 \\
\hline & & Syacium papillosum & Dusky flounder & 10 & - \\
\hline & Cynoglossidae & Symphurus plagiusa & Blackcheek tonguefish & 20 & 13 \\
\hline & Paralichthyidae & Citharichthys spilopterus & Bay whiff & 15 & 22 \\
\hline & & Etropus crossotus & Fringed flounder & 30 & 24 \\
\hline Scorpaeniformes & Triglidae & Prionotus longispinosus & Bigeye searobin & 47 & 56 \\
\hline & & Prionotus paralatus & Mexican searobin & 25 & - \\
\hline & & Prionotus rubio & Blackwing searobin & 15 & 16 \\
\hline & & Prionotus stearnsi & Shortwing searobin & 28 & - \\
\hline Siluriformes & Ariidae & Arius felis & Hardhead catfish & - & 22 \\
\hline
\end{tabular}


Table 1 (continued)

\begin{tabular}{|c|c|c|c|c|c|}
\hline \multirow{2}{*}{$\begin{array}{l}\text { CLASS } \\
\text { Order }\end{array}$} & \multirow[t]{2}{*}{ Family } & \multirow[t]{2}{*}{ Scientific name } & \multirow[t]{2}{*}{ Common name } & \multicolumn{2}{|c|}{$\%$ trawls present } \\
\hline & & & & Summer & Fall \\
\hline \multirow[t]{4}{*}{ Tetraodontiformes } & Balistidae & Balistes capriscus & Gray triggerfish & 13 & 38 \\
\hline & Monacanthidae & Monacanthus hispidus & Planehead filefish & 20 & - \\
\hline & Tetraodontidae & Lagocephalus laevigatus & Smooth puffer & 29 & 26 \\
\hline & & Sphoeroides parvus & Least puffer & 36 & 31 \\
\hline \multicolumn{6}{|l|}{ ANTHOZOA } \\
\hline Pennatulacea & Renillidae & Renilla mulleri & Sea pansy & 11 & - \\
\hline \multicolumn{6}{|l|}{ ASTEROIDEA } \\
\hline Paxillosida & Astropectinidae & Astropecten duplicatus & Two-spined star fish & 17 & 20 \\
\hline \multicolumn{6}{|l|}{ BIVALVIA } \\
\hline Ostreoida & Pectinidae & Amusium papyraceum & Paper scallop & 14 & 10 \\
\hline \multicolumn{6}{|l|}{ CEPHALOPODA } \\
\hline \multirow[t]{3}{*}{ Teuthida } & Loliginidae & Loligo pealeii & Longfin inshore squid & 38 & 24 \\
\hline & & Loligo pleii & Arrow squid & 40 & 28 \\
\hline & & Lolliguncula brevis & Atlantic brief squid & 27 & 20 \\
\hline \multicolumn{6}{|l|}{ MALACOSTRACA } \\
\hline \multirow[t]{12}{*}{ Decapoda } & Calappidae & Calappa sulcata & Yellow box crab & 21 & 20 \\
\hline & Penaeidae & Penaeus aztecus & Brown shrimp & 88 & 91 \\
\hline & & Penaeus duorarum & Northern pink shrimp & 23 & 21 \\
\hline & & Penaeus setiferus & Northern white shrimp & 16 & 31 \\
\hline & & Trachypenaeus similis & Roughback shrimp & 37 & 33 \\
\hline & Portunidae & Callinectes sapidus & Blue crab & 23 & 12 \\
\hline & & Callinectes similis & Lesser blue crab & 80 & 78 \\
\hline & & Portunus gibbesii & Iridescent swimming crab & 44 & 55 \\
\hline & & Portunus spinicarpus & Longspine swimming crab & 21 & 10 \\
\hline & & Portunus spinimanus & Blotched swimming crab & 21 & 20 \\
\hline & Sicyoniidae & Sicyonia brevirostris & Brown rock shrimp & 36 & 25 \\
\hline & & Sicyonia dorsalis & Lesser rock shrimp & 44 & 24 \\
\hline \multirow[t]{2}{*}{ Stomatopoda } & Squillidae & Squilla chydaea & Mantis shrimp & 24 & 18 \\
\hline & & Squilla empusa & Mantis shrimp & 48 & 45 \\
\hline
\end{tabular}

a

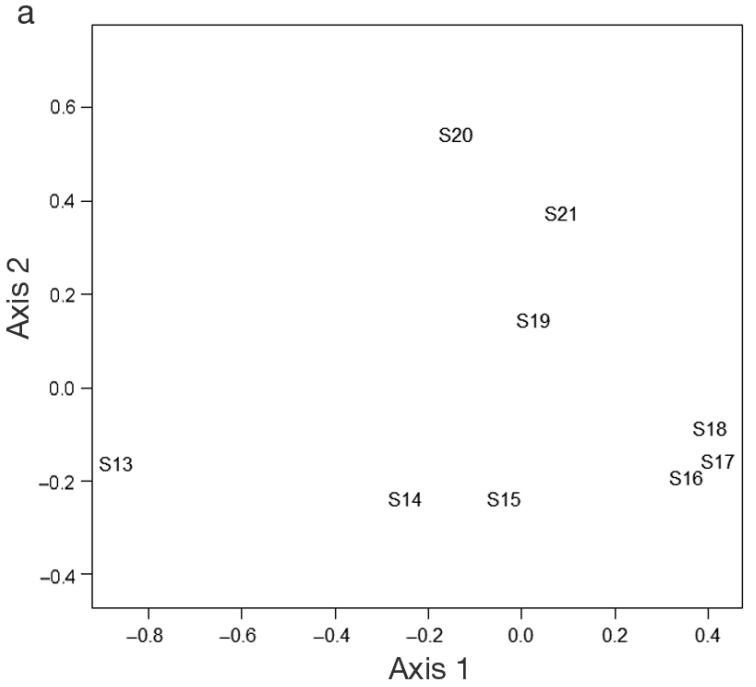

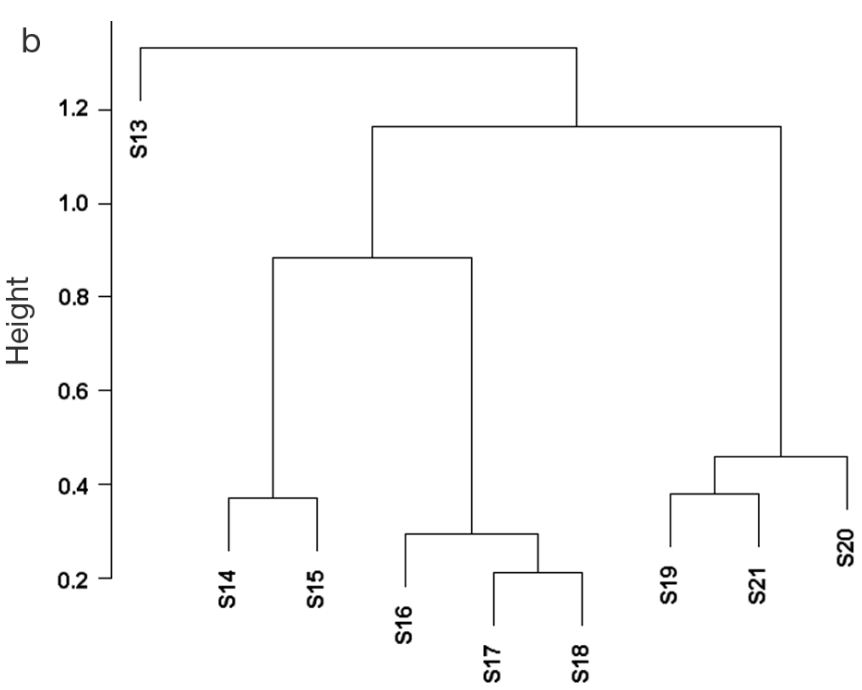

Fig. 2. (a) Nonmetric multidimensional scaling and (b) cluster analysis results for the summer groundfish trawl survey in the northwestern Gulf of Mexico. Data by year for each shrimp statistical zone were pooled to determine overall community structure among the zones. In the dendrogram (b), height measures the similarity of species composition within a branch. Smaller values indicate greater similarity 

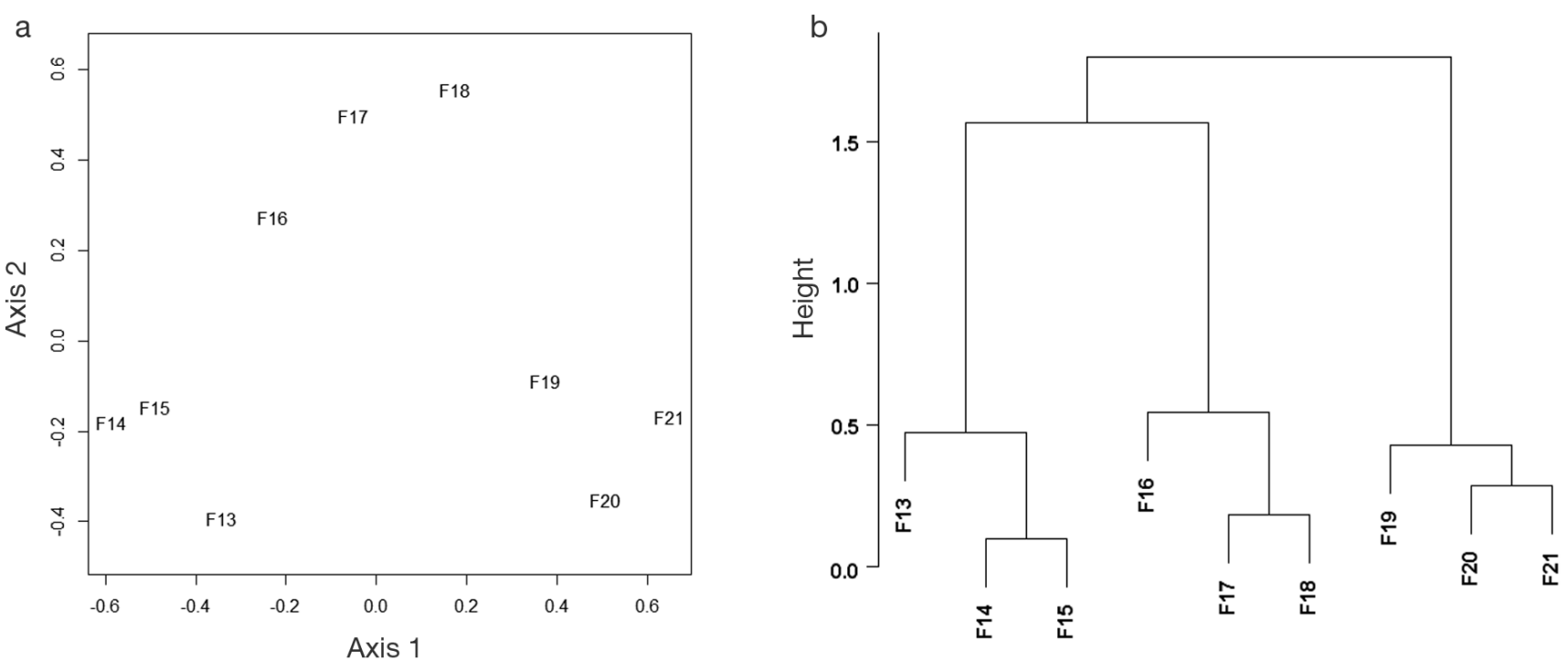

Fig. 3. (a) Nonmetric multidimensional scaling and (b) cluster analysis results for the fall groundfish trawl survey in the northwestern Gulf of Mexico. Other details as in Fig. 2

River and moving westward. The 4 DFCs will be denoted as Zone 13 DFC, East DFC (representing Zones 14 and 15), Mid DFC (representing Zones 16 to 18), and West DFC (representing Zones 19 to 21).

\section{Fall groundfish survey}

Two axes (stress $=0.004$ ) in the NMDS explained the fall survey data. The first axis represents a longitudinal shift in community assemblages from the Mississippi River to the Texas/Mexico border (Fig. 3a). Zone 13 was the only zone that did not fall in numerical order with the other zones, but still grouped with Zones 14 and 15. The shrimp statistical zones formed 3 distinct groups, Zones 13 to 15 , Zones 16 to 18, and Zones 19 to 21 .

The cluster analysis from the fall survey revealed the same pattern as the NMDS with 3 regional clusters, and quantifies the differences among DFCs (Fig. 3b). Zones 13, 16, and 19 had a higher height value than other shrimp statistical zones within their respective branches of the dendrogram, which suggests these could be transition zones among fish assemblages.

\section{Community structure and indicator species}

No more than 11 species contributed to the $90 \%$ cumulative difference in dissimilarity between any 2 regions in either season, with fewer species dominating the dissimilarity in the fall survey (Tables $2 \& 3$ ).
In the summer survey, Zone 13 was only compared to the collective of all other DFCs, as it formed a distinct branch in the cluster analysis (Fig. 2). All species contributing to the cumulative $90 \%$ dissimilarities also had indicator values of $\geq 25$ for 1 of the DFCs in the fall survey (Table 4). In the summer survey, Gulf butterfish, blackear bass, and arrow squid (scientific names provided in Table 1) contributed to dissimilarity among DFCs, but were not identified as indicator species.

Longspine porgy and Atlantic croaker, 2 of the more commonly abundant species in both surveys, accounted for a total of $\sim 91 \%$ of the dissimilarity between the East and Mid DFCs in the fall and 28\% in the summer (Table 2). Both species are indicators in both the summer and fall surveys, with Atlantic croaker identifying with the East DFC and longspine porgy with the Mid DFC.

Four of the species contributing to the difference between Zone 13 and all other DFCs were also indicator species for Zone 13 in the summer survey: roughback shrimp, bigeye searobin, a mantis shrimp (Squilla empusa), and Atlantic cutlassfish. Of these, roughback shrimp contributed $\sim 22 \%$ to the dissimilarity, with the other 3 contributing an additional $\sim 16 \%$.

In order to compare indicator species between the summer and fall surveys, Zone 13 was separated from the East DFC in the fall indicator analysis. All of the DFCs shared at least 1 indicator species in common between the summer and fall surveys (Table 4). Species with relatively high indicator values $(\geq 50)$ include the Atlantic bumper (Fall West DFC), At- 
Table 2. Species accounting for $90 \%$ of the dissimilarity between any 2 demersal fish communities (DFCs) in the summer surveys of the northwestern Gulf of Mexico. The maximum group is from the indicator species analysis and is the region where the species is most prevalent. Scientific names of species are given in Table 1

\begin{tabular}{|lcccc|}
\hline Species & $\bar{\delta}_{i}$ & $\mathrm{SD}\left(\bar{\delta}_{i}\right)$ & $\bar{\delta}_{i} / \mathrm{SD}\left(\bar{\delta}_{i}\right)$ & $\Sigma \bar{\delta}_{i} \%$ \\
\hline East vs. Mid DFCs & & & & \\
Roughback shrimp & 0.16 & 0.016 & 10.14 & 26.33 \\
Longspine porgy & 0.11 & 0.067 & 1.71 & 45.10 \\
Bigeye searobin & 0.08 & 0.056 & 1.35 & 57.42 \\
Atlantic croaker & 0.06 & 0.058 & 1.03 & 67.33 \\
Brown rock shrimp & 0.03 & 0.024 & 1.38 & 72.80 \\
Gulf butterfish & 0.03 & 0.031 & 0.97 & 77.68 \\
Mantis shrimp & 0.03 & 0.007 & 3.89 & 82.31 \\
$\quad$ Squilla empusa) & & & & \\
Brown shrimp & 0.02 & 0.013 & 1.29 & 85.06 \\
Lesser blue crab & 0.02 & 0.007 & 2.30 & 87.57 \\
Blackear bass & 0.01 & 0.005 & 1.47 & 88.97 \\
Iridescent swimming crab & 0.01 & 0.005 & 1.76 & 90.30 \\
East vs. West DFCs & & & & \\
Brown shrimp & 0.24 & 0.109 & 2.23 & 35.96 \\
Bigeye searobin & 0.08 & 0.062 & 1.24 & 47.45 \\
Atlantic croaker & 0.08 & 0.060 & 1.27 & 58.76 \\
Longspine porgy & 0.07 & 0.089 & 0.74 & 68.53 \\
Roughback shrimp & 0.05 & 0.045 & 1.18 & 76.44 \\
Arrow squid & 0.04 & 0.012 & 3.24 & 82.08 \\
Mantis shrimp (S. empusa) & 0.02 & 0.010 & 2.21 & 85.15 \\
Gulf butterfish & 0.02 & 0.023 & 0.80 & 87.77 \\
Lesser blue crab & 0.02 & 0.020 & 0.81 & 90.17 \\
Mid vs. West DFCs & & & & \\
Brown shrimp & 0.32 & 0.121 & 2.61 & 43.21 \\
Longspine porgy & 0.22 & 0.129 & 1.67 & 72.68 \\
Lesser blue crab & 0.04 & 0.029 & 1.50 & 78.73 \\
Roughback shrimp & 0.04 & 0.045 & 0.86 & 84.11 \\
Brown rock shrimp & 0.03 & 0.023 & 1.33 & 88.42 \\
Arrow squid & 0.02 & 0.010 & 2.05 & 91.19 \\
Zone 13 vs. all other DFCs & & & & \\
Longspine porgy & 0.44 & 0.200 & 2.22 & 41.48 \\
Roughback shrimp & 0.23 & 0.089 & 2.61 & 63.23 \\
Brown shrimp & 0.08 & 0.127 & 0.66 & 71.06 \\
Bigeye searobin & 0.08 & 0.038 & 2.18 & 78.75 \\
Mantis shrimp (S. empusa) & 0.07 & 0.021 & 3.26 & 85.26 \\
Atlantic cutlassfish & 0.03 & 0.004 & 6.06 & 87.71 \\
Arrow squid & 0.02 & 0.019 & 1.02 & 89.45 \\
Atlantic croaker & 0.01 & 0.028 & 0.50 & 90.81 \\
& & & & \\
\hline
\end{tabular}

lantic croaker (Fall East DFC), Atlantic cutlassfish (Summer and Fall Zone 13 DFC), brown shrimp (Summer West DFC), dwarf goatfish (Summer West DFC), longspine porgy (Fall Mid DFC), northern white shrimp (Fall Zone 13 DFC; Table 4).

Four species were identified as indicator species within different DFCs between the summer and fall surveys: bigeye searobin, lesser blue crab, iridescent swimming crab, and red snapper. Except for the lesser blue crab, each species appeared as an indicator species in an adjacent DFC between the fall and
Table 3. Species accounting for $90 \%$ of the dissimilarity between any 2 demersal fish communities (DFCs) in the fall surveys of the northwestern Gulf of Mexico. Other details as in Table 2

\begin{tabular}{|lcccc|}
\hline Species & $\bar{\delta}_{i}$ & $\mathrm{SD}\left(\bar{\delta}_{i}\right)$ & $\bar{\delta}_{i} / \mathrm{SD}\left(\bar{\delta}_{i}\right)$ & $\Sigma \bar{\delta}_{i} \%$ \\
\hline East vs. Mid DFCs & & & & \\
Longspine porgy & 0.58 & 0.070 & 8.21 & 61.54 \\
Atlantic croaker & 0.28 & 0.160 & 1.73 & 91.13 \\
East vs. West DFCs & & & & \\
Atlantic croaker & 0.44 & 0.096 & 4.56 & 39.88 \\
Atlantic bumper & 0.33 & 0.048 & 6.92 & 70.15 \\
Brown shrimp & 0.08 & 0.044 & 1.80 & 77.32 \\
Shoal flounder & 0.04 & 0.015 & 2.86 & 81.27 \\
Roughback shrimp & 0.04 & 0.038 & 0.98 & 84.61 \\
Longspine porgy & 0.04 & 0.043 & 0.83 & 87.89 \\
Dwarf sand perch & 0.03 & 0.012 & 2.78 & 90.80 \\
Mid vs. West DFCs & & & & \\
Longspine porgy & 0.35 & 0.151 & 2.29 & 34.70 \\
Atlantic bumper & 0.29 & 0.066 & 4.40 & 63.95 \\
Atlantic croaker & 0.08 & 0.103 & 0.78 & 72.00 \\
Brown shrimp & 0.07 & 0.035 & 2.10 & 79.47 \\
Roughback shrimp & 0.05 & 0.039 & 1.37 & 84.84 \\
Shoal flounder & 0.04 & 0.014 & 3.05 & 89.03 \\
Dwarf sand perch & 0.03 & 0.016 & 1.61 & 91.59 \\
\hline
\end{tabular}

summer surveys. The lesser blue crab had a significant indicator value for the West DFC in the summer survey and the Zone $13 \mathrm{DFC}$ in the fall survey.

\section{DISCUSSION}

The demersal fish community associated with the shrimp trawl fishery in the northwestern GOM-LME exhibits spatial and seasonal structure. Four distinct DFCs were identified from the summer SEAMAP data, and 3 DFCs were identified from the fall SEAMAP data. The same shrimp statistical zones comprised the West and Mid DFCs in both fall and summer surveys. Zone 13, the shrimp statistical zone nearest the Mississippi River, was similar to Zones 14 and 15 in the fall survey, but was dissimilar to all other zones in the summer survey. The overall similarity in spatial segregation of the shrimp statistical zones between surveys, even though dominant species differ, provides strong evidence of a changing fish community along the continental shelf.

The results from this study reflect the community associated with the shrimp trawl fishery from a fisheries-independent study, and may differ from the community of bycatch in the shrimp trawl fleet. The shrimp trawl fishery participated in a voluntary observer program from 1992 to 2006 and has been subject to a mandatory observer program only since 
Table 4. Species with statistically significant indicator values $(\geq 25)$ for each demersal fish community (DFC). Indicator values for species appearing in both surveys are denoted as summer (S) and fall (F). Scientific names of species are given in Table 1

\begin{tabular}{|llll|}
\hline DFC & Summer survey & Fall survey & Both surveys \\
\hline Zone 13 & Bigeye searobin (37) & Northern white shrimp (64) & Atlantic cutlassfish (S: 51; F: 52) \\
& $\begin{array}{l}\text { Ragged goby (30) } \\
\text { Rock sea bass (29) }\end{array}$ & Lesser blue crab (42) & Mantis shrimp (Squilla empusa) (S: 41; F: 46) \\
& & Iridescent swimming crab (37) & Sand seatrout (S: 41; F: 42) \\
& & Atlantic midshipman (35) & Atlantic brief squid (S: 40; F: 34) \\
East & Iridescent swimming crab (37) & Bigeye searobin (34) & Roughback shrimp (S: 26; F: 32) \\
& Fringed flounder (27) & Spot croaker (30) & Atlantic croaker (S: 25; F: 53) \\
Mid & Red snapper (31) & Gray triggerfish (29) & \\
& & & Brown rock shrimp (S: 41; F: 39) \\
& & & Longspine porgy (S: 35; F: 50) \\
\multirow{4}{*}{ West } & Dwarf goatfish (53) & Atlantic bumper (62) & Lane snapper (S: 26; F: 40) \\
& Lesser blue crab (32) & Dwarf sand perch (47) & Lesser rock shrimp (S: 28; F: 29) \\
& Shortwing searobin (25) & Red snapper (33) & Brazilian lizardfish (S: 25; F: 34) \\
& & Shoal flounder (33) & \\
& & Two-spined star fish (31) & \\
& & Scaled herring (25) & \\
& & & \\
\hline
\end{tabular}

2007 (GMFMC 2005). Turtle excluder devices have been required on all shrimp trawls since 1992 (US Government 1992), and bycatch reduction devices have been required in the western GOM since 1998 (US Government 1998), although neither device is used during the SEAMAP survey. The SEAMAP survey follows a stratified random sampling design, whereas the shrimp trawl fleet actively targets specific areas of known shrimp abundance. For instance, Atlantic bumper was identified as an indicator species for the fall survey West DFC and contributed strongly to the dissimilarity between DFCs, but is not listed as a documented species in the most recent shrimp trawl bycatch report (Scott-Denton et al. 2012). The same is true for bigeye searobin, which was identified as an indicator species in both surveys, and was identified as a good discriminating species in the summer survey. Nevertheless, we expect that species caught as bycatch in the shrimp fishery would be effectively monitored by the SEAMAP survey, and overall, the SEAMAP is a useful tool to understand spatial patterns of species composition and trends in the life stages sampled.

Two factors contributing to the change in dominant species communities from summer to fall are the environmental conditions in the GOM as well as species' life history characteristics and timing of spawning. In particular, Zone 13 and the East DFC are subject to unique environmental factors and are heavily influenced by their proximity to the mouth of the Mississippi and Atchafalaya Rivers (Turner \& Rabalais 1994, Rabalais et al. 1996, Alexander et al. 2000). Simulations have shown that the physical drivers create a number of different circulation patterns in the Louisiana Bight, including seasonal clockwise and anticyclonic gyres (Wang \& Justi 2009).

The summer SEAMAP groundfish trawl survey is conducted from mid-June to the end of July, which is the peak timing for the annual hypoxia event in the northwestern GOM (Rabalais et al. 1994, 2002b). Hypoxia is defined as bottom-water oxygen levels $\leq 2 \mathrm{mg} \mathrm{l}^{-1}$ and occurs on the Louisiana/Texas continental shelf from May to September. Hypoxic waters were detected in all DFCs at least once. Although hypoxia off the coast of Louisiana typically occurs at depths of 5 to $30 \mathrm{~m}$ (Rabalais et al. 2002a), hypoxic waters were detected in $39 \%$ of summer trawls in Zone 13 and $26 \%$ of summer trawls in the East DFC (for which environmental data were available). For tows with environmental data, the average oxygen level was $\leq 2 \mathrm{mg} \mathrm{l}^{-1}$ in the Zone 13 summer stations in 7 survey years $(1991,1992,1997,2000,2002,2007$, 2008) as well in both the summer and fall surveys in the East DFC in 1997; for yearly averages of dissolved oxygen (DO) by DFC see Fig. S2 in the Supplement. However, no significant trends were detected in community assemblages when DO was used as a covariate in the multivariate analyses. Species such as Atlantic bumper and sand seatrout exhibit markedly low DO thresholds (between 1.06 and $1.16 \mathrm{mg} \mathrm{l}^{-1}$ ), which may explain the lack of significant results in this study (Craig 2012). Craig (2012) also found that Atlantic croaker and Atlantic cutlassfish (both species associating with Zone 13) have DO thresholds below $2.0 \mathrm{mg} \mathrm{l}^{-1}$. Trends may also not have been detected because DO is only 
measured at one point during the SEAMAP trawl, and does not necessarily reflect the environment over an entire tow. Furthermore, trawls at 10 to $30 \mathrm{fm}$ $(18.3-54.9 \mathrm{~m})$ are at the offshore edges of the hypoxic areas, where the bottom hypoxic layer is thin compared to inshore areas (Obenour et al. 2013). Mobile fish are also able to suspend above and behaviorally avoid the hypoxic waters (Wannamaker \& Rice 2000, Bell \& Eggleston 2005, Hazen et al. 2009, Craig 2012), but may still be captured in the trawl survey. Direct comparisons between the summer and fall surveys from Zone 13 incorporating additional environmental data (e.g. Mississippi River outflow, nutrient loading, upwelling/downwelling events) could explain some of the species trends observed.

The life history characteristics and time of spawning of the bycatch species also influence species susceptibility to the trawl. Northern red snapper and Atlantic croaker are 2 examples of species predominately caught as bycatch as age- 0 and age- 1 fish, but exhibit different life history patterns (Diamond et al. 2000, Wilson \& Nieland 2001). Young-of-the-year (age-0) red snapper settle onto trawlable, low-relief habitat in the fall months, whereas age- 1 fish move to more complex habitat and deeper waters in the fall (Patterson 2007). Atlantic croaker migrate to offshore waters in the late juvenile stage, which is reflected in the increased median length of fish from the summer to fall surveys (Diamond et al. 1999). The distribution of lengths revealed the same pattern for 6 other species we examined, where the summer catch was a mix of juvenile and adult fish and the fall catch was dominated by mature individuals (bigeye searobin, Gulf butterfish, inshore lizardfish, longspine porgy, sand seatrout, and silver seatrout; see Fig. S3 for length distributions of select species and Table S3 for life history information). Examining length frequencies across a broader range of depths confirms that the average size of these 6 species (except inshore lizardfish) was larger at depths greater than $30 \mathrm{fm}(54.9 \mathrm{~m})$, providing more evidence for the ontogenetic shifts occurring in these species. The ontogenetic shifts in habitat use and seasonal migrations of species add a level of complexity to disentangling patterns in species biomass from the natural variability in juvenile population sizes. This also confounds the ability to assess population level changes and the effect of the shrimp trawl bycatch mortality on population trajectories simply from the survey index. A more synoptic picture that included surveys covering the entire species spatial range as well as information about all removals (catch, bycatch) would be needed to understand the population dynamics of the various species.
Basic life history information, including length-atmaturity, time of spawning, maximum age, and maximum size, is lacking for the majority of bycatch species. Fewer than $5 \%$ of the species encountered in the survey are considered economically or ecologically important, as defined by Scott-Denton et al. (2012). Eight of the 32 indicator species identified in this study are harvested in the GOM. Formal stock assessments have only been conducted for red snapper, lane snapper, and gray triggerfish, in addition to the shrimp species. Other economically and ecologically important species identified as indicators were Atlantic croaker, longspine porgy, and sand seatrout.

As we move towards EBFM, additional research is needed to understand the dynamics of species and communities that are not currently well studied. The SEAMAP groundfish survey is the only longterm fisheries-independent survey available in the GOM-LME. In addition to fisheries stock assessments, the SEAMAP survey data are used to inform ecosystem models for the GOM (Walters et al. 2008, Drexler \& Ainsworth 2013, Grüss et al. 2014). The importance of defining the spatial community dynamics of a system has become apparent as we move towards EBFM (Mangel \& Levin 2005). The regional and seasonal demersal fish communities identified in this study can be used to monitor the GOM-LME, aid in marine spatial planning, and be incorporated in ecological models. Studies on both the west coast (Jay 1996, Williams \& Ralston 2002, Tolimieri \& Levin 2006) and east coast (Shertzer \& Williams 2008, Auster \& Link 2009, Shertzer et al. 2009) of the USA have examined the spatial and temporal variability in fish assemblages. Depending on the orientation of the study area, these studies found either latitudinal or longitudinal (Aleutian Islands; Logerwell \& Aydin 2005) gradients for species assemblages. On Georges Bank, species compositions have shifted, but trophic guilds have remained relatively consistent through time (Garrison \& Link 2000). In the Chesapeake Bay, which is driven by the Susquehanna River outflow (much like Zone 13 in our study), species assemblages have a spatial and seasonal component but have been resilient to environmental perturbations (Jung \& Houde 2003). These studies all contribute to the baseline understanding of species assemblages and their contribution to EBFM. In the GOM, the assemblages identified can be used as a baseline to monitor future changes resulting from shrimp fishery effort reduction or any other physical and environmental drivers. 
Acknowledgements. We thank C. D'Elia, J. Cowan, K. Rose, B. Marx, J. Rester, J. Nance, and the Gulf States Marine Fisheries Commission for providing the SEAMAP bottom trawl data. We also thank Brenda Bowling (Texas Parks and Wildlife Department) for use of the fish photographs. Comments from 4 anonymous reviewers also improved the manuscript. Support was provided by Louisiana State University and the NMFS Sea Grant Population Dynamics Fellowship NA09OAR4170117.

\section{LITERATURE CITED}

Alexander RB, Smith RA, Schwarz GE (2000) Effect of stream channel size on the delivery of nitrogen to the Gulf of Mexico. Nature 403:758-761

- Auster PJ, Link JS (2009) Compensation and recovery of feeding guilds in a northwest Atlantic shelf fish community. Mar Ecol Prog Ser 382:163-172

Barnes PW, Thomas JP (2005) Benthic habitats and the effects of fishing. American Fisheries Society, Bethesda, MD

> Bell GW, Eggleston DB (2005) Species-specific avoidance responses by blue crabs and fish to chronic and episodic hypoxia. Mar Biol 146:761-770

Board OS (2002) Effects of trawling and dredging on seafloor habitat. The National Academies Press, Washington, DC

Bohnsack JA (1998) Ecosystem management, marine reserves, and the art of airplane maintenance. Proc Gulf Caribb Fish Inst 50:304-311

Chittenden ME, McEachran JD (1976) Composition, ecology, and dynamics of demersal fish communities on the northwestern Gulf of Mexico continental shelf, with a similar synopsis for the entire Gulf. Sea Grant Publication SG-76-208, Texas A\&M University Press, College Station, TX

Churchill JH (1989) The effect of commercial trawling on sediment resuspension and transport over the Middle Atlantic Bight continental shelf. Cont Shelf Res 9:841-865

- Clarke KR (1993) Non parametric multivariate analyses of changes in community structure. Aust J Ecol 18:117-143

Clarke KR, Warwick RM (2001) Change in marine communities: an approach to statistical analysis and interpretation. PRIMER-E, Plymouth

Conners M, Hollowed A, Brown E (2002) Retrospective analysis of Bering Sea bottom trawl surveys: regime shift and ecosystem reorganization. Prog Oceanogr 55:209-222

> Craig JK (2012) Aggregation on the edge: effects of hypoxia avoidance on the spatial distribution of brown shrimp and demersal fishes in the Northern Gulf of Mexico. Mar Ecol Prog Ser 445:75-95

Diamond SL, Crowder LB, Cowell LG (1999) Catch and bycatch: the qualitative effects of fisheries on population vital rates of Atlantic croaker. Trans Am Fish Soc 128: 1085-1105

> Diamond SL, Cowell LG, Crowder LB (2000) Population effects of shrimp trawl bycatch on Atlantic croaker. Can J Fish Aquat Sci 57:2010-2021

> Drexler M, Ainsworth CH (2013) Generalized additive models used to predict species abundance in the Gulf of Mexico: an ecosystem modelling tool. PLoS ONE 8: e64458

Dufrene M, Legendre P (1997) Species assemblages and indicator species: the need for a flexible asymmetrical approach. Ecol Monogr 67:345-366

> Duplisea DE, Jennings S, Warr KJ, Dinmore TA (2002) A size-based model of the impacts of bottom trawling on benthic community structure. Can J Fish Aquat Sci 59: 1785-1795

Eldridge P (1988) The southeast area monitoring and assessment program (SEAMAP): a state-federal-university program for collection, management, and dissemination of fishery-independent data and information in the southeastern United States. Mar Fish Rev 50:29-39

Gallaway BJ, Cole JG, Martin LR, Nance JM, Longnecker M (2003) An evaluation of an electronic logbook as a more accurate method of estimating spatial patterns of trawling effort and bycatch in the Gulf of Mexico shrimp fishery. N Am J Fish Manag 23:787-809

Garrison LP, Link JS (2000) Dietary guild structure of the fish community in the Northeast United States continental shelf ecosystem. Mar Ecol Prog Ser 202:231-240

GMFMC (Gulf of Mexico Fishery Management Council) (2005) Amendment 13 to the Fishery Management Plan for the Shrimp Fishery of the Gulf of Mexico. GMFMC, Tampa, FL

Grüss A, Drexler M, Ainsworth CH (2014) Using delta generalized additive models to produce distribution maps for spatially explicit ecosystem models. Fish Res 159:11-24

Hazen EL, Craig JK, Good CP, Crowder LB (2009) Vertical distribution of fish biomass in hypoxic waters on the Gulf of Mexico shelf. Mar Ecol Prog Ser 375:195-207

> Jay C (1996) Distribution of bottom-trawl fish assemblages over the continental shelf and upper slope of the US west coast, 1977-1992. Can J Fish Aquat Sci 53:1203-1225

Jung S, Houde E (2003) Spatial and temporal variabilities of pelagic fish community structure and distribution in Chesapeake Bay, USA. Estuar Coast Shelf Sci 58: 335-351

Koch C (1987) Prediction of sample size effects on the measured temporal and geographic distribution patterns of species. Paleobiology 13:100-107

Kruskal J (1964) Multidimensional scaling by optimizing goodness of fit to a nonmetric hypothesis. Psychometrika 29:1-27

Legendre P, Legendre L (1998) Numerical ecology, Vol 20. Elsevier Science \& Technology, Amsterdam

Link JS (2010) Ecosystem-based fisheries management: confronting tradeoffs. Cambridge University Press, New York, NY

$>$ Logerwell E, Aydin K (2005) Geographic patterns in the demersal ichthyofauna of the Aleutian Islands. Fish Oceanogr 14:93-112

Løkkeborg S (2005) Impacts of trawling and scallop dredging on benthic habitats and communities. Fish Tech Pap 472. FAO, Rome

Maechler M, Rousseeuw P, Struyf A, Hubert M, Hornik K (2002) Cluster: cluster analysis basics and extensions. $\mathrm{R}$ package version 1.14.2. http://cran.r-project.org/web/ packages/cluster/index.html

Mangel M, Levin PS (2005) Regime, phase and paradigm shifts: making community ecology the basic science for fisheries. Philos Trans R Soc Lond B Biol Sci 360:95-105

McCune B, Mefford M (2006) PC-ORD. Multivariate analysis of ecological data, Version 5. MjM Software Design, Gleneden Beach, OR

McCune B, Grace J, Urban D (2002) Analysis of ecological communities. MjM Software Design, Gleneden Beach, OR

Monk MH (2012) Identification and incorporation of quantitative indicators of ecosystem function into single-species fishery stock assessment models and the associated biological reference points. PhD dissertation, Louisiana State University, Baton Rouge, LA 
Mueter F, Norcross B (2000) Changes in species composition of the demersal fish community in nearshore waters of Kodiak Island, Alaska. Can J Fish Aquat Sci 57:1169-1180

NOAA (National Oceanic and Atmospheric Administration) (2008) NOAA Ship Oregon II Cruise 08-06 (284) October 8-November 18, 2008. US Department of Commerce, Pascagoula, MS

Obenour DR, Scavia D, Rabalais NN, Turner RE, Michalak AM (2013) Retrospective analysis of midsummer hypoxic area and volume in the northern Gulf of Mexico, 19852011. Environ Sci Technol 47:9808-9815

Oksanen J, Blanchet F, Kindt R, Legendre P and others (2010) Vegan: community ecology package. R package version 1.17-4. http://cran.r-project.org/web/packages/ vegan/index.html

> Orloci L (1967) An agglomerative method for classification of plant communities. J Ecol 55:193-206

Patella F (1975) Water surface area within statistical subareas used in reporting Gulf coast shrimp data. Mar Fish Rev 37:22-24

Patterson WF III (2007) A review of Gulf of Mexico red snapper movement studies: implications for population structure. In: Patterson WF III, Cowan JH Jr, Fitzhugh GR, Nieland DL (eds) Red snapper ecology and fisheries in the US. American Fisheries Society Symposium 60, Bethesda, MD, p 245-262

Pikitch EK, Santora C, Babcock EA, Bakun A and others (2004) Ecosystem-based fishery management. Science 305:346-347

R Core Development Team (2011) R: a language and environment for statistical computing. $\mathrm{R}$ Foundation for Statistical Computing, Vienna. www.r-project.org

Rabalais NN, Wiseman WJ, Turner RE (1994) Comparison of continuous records of near-bottom dissolved oxygen from the hypoxia zone along the Louisiana coast. Estuaries Coasts 17:850-861

Rabalais NN, Turner RE, Justi D, Dortch Q, Wiseman WJ, Gupta BKS (1996) Nutrient changes in the Mississippi River and system responses on the adjacent continental shelf. Estuaries 19:386-407

Rabalais N, Turner R, Scavia D (2002a) Beyond science into policy: Gulf of Mexico hypoxia and the Mississippi River. Bioscience 52:129-142

Rabalais NN, Turner RE, Wiseman W Jr (2002b) Gulf of Mexico hypoxia, aka 'The Dead Zone'. Annu Rev Ecol Syst 33:235-263

Rester JK, Sanders N, Pellegrin GJ (2008) SEAMAP environmental and biological atlas of the Gulf of Mexico, 2002. Ocean Springs, MS

Rice JC (2000) Evaluating fishery impacts using metrics of community structure. ICES J Mar Sci 57:682-688

Scott-Denton E, Cryer PF, Duffy MR, Gocke JP and others (2012) Characterization of the U.S. Gulf of Mexico and South Atlantic penaeid and rock shrimp fisheries based on observer data. Mar Fish Rev 74:1-27

Shepard R (1962) The analysis of proximities: multidimensional scaling with an unknown distance function. II.

Editorial responsibility: Kenneth Sherman,

Narragansett, Rhode Island, USA
Psychometrika 27:219-246

Shertzer KW, Williams EH (2008) Fish assemblages and indicator species: reef fishes off the southeastern United States. Fish Bull 106:257-269

Shertzer KW, Williams EH, Taylor J (2009) Spatial structure and temporal patterns in a large marine ecosystem: exploited reef fishes of the southeast United States. Fish Res 100:126-133

Stanley DR, Wilson CA (1997) Seasonal and spatial variation in the abundance and size distribution of fishes associated with a petroleum platform in the northern Gulf of Mexico. Can J Fish Aquat Sci 54:1166-1176

Tolimieri N, Levin P (2006) Assemblage structure of eastern Pacific groundfishes on the US continental slope in relation to physical and environmental variables. Trans Am Fish Soc 135:317-332

Turner RE, Rabalais NN (1994) Coastal eutrophication near the Mississippi river delta. Nature 368:619-621

US Government (1992) Threatened fish and wildlife: threatened marine reptiles: revisions to enhance and facilitate compliance with sea turtle conservation requirements applicable to shrimp trawlers: restrictions applicable to shrimp trawlers and other fisheries. US Fed Reg 57 (234):57348-57358

US Government (1998) Fisheries of Caribbean, Gulf of Mexico, and the South Atlantic: shrimp fishery of the Gulf of Mexico: bycatch reduction device certification. US Fed Reg 63 (96):27499-27501

Walters C, Martell SJD, Christensen V, Mahmoudi B (2008) An Ecosim model for exploring Gulf of Mexico ecosystem management options: implications of including multistanza life-history models for policy predictions. Bull Mar Sci 83:251-271

Wang L, Justić D (2009) A modeling study of the physical processes affecting the development of seasonal hypoxia over the inner Louisiana-Texas shelf: circulation and stratification. Cont Shelf Res 29:1464-1476

Wannamaker CM, Rice JA (2000) Effects of hypoxia on movements and behavior of selected estuarine organisms in the southeastern United States. J Exp Mar Biol Ecol 249:145-163

Ward JH (1963) Hierarchical grouping to optimize an objective function. J Am Stat Assoc 58:236-244

Watling L, Norse EA (1998) Disturbance of the seabed by mobile fishing gear: a comparison to forest clearcutting. Conserv Biol 12:1180-1197

Wells RJ, Cowan JH Jr, Patterson WF III, Walters CJ (2008) Effect of trawling on juvenile red snapper (Lutjanus campechanus) habitat selection and life history parameters. Can J Fish Aquat Sci 65:2399-2411

Williams EH, Ralston S (2002) Distribution and co-occurrence of rockfishes (family: Sebastidae) over trawlable shelf and slope habitats of California and southern Oregon. Fish Bull 100:836-855

Wilson CA, Nieland DL (2001) Age and growth of red snapper, Lutjanus campechanus, from the northern Gulf of Mexico off Louisiana. Fish Bull 99:653-664

Submitted: May 21, 2014; Accepted: December 1, 2014

Proofs received from author(s): December 22, 2014 